コンファレンスレポート

OSA (米国光学会) を通してみた中赤外領域 $(5 \sim 20 \mu \mathrm{m})$

波長可変レーザーの開発現況

\title{
佐藤 博保 ${ }^{*}$
}

(1995年10月30日 受理)

\section{Present Status of Tunable Lasers in the Mid-IR Region (5 20 $\mu \mathrm{m})$ as Viewed through the OSA Meeting}

\author{
Hiroyasu SATO* \\ (Received October 30, 1995)
}

\section{1.はじめに}

中赤外領域 $(5 \sim 20 \mu \mathrm{m})$ は, 波数でいえば $2000 \sim 500 \mathrm{~cm}^{-1} に$ にたり，化学者にとって非常 に重要な領域である。それは, 分子の振動バン ドのうち主要なものがほとんどこの領域にみら れるからで,このスペクトル領域は，個々の分 子を識別するための「指紋領域」とよばれるも のを含む。ところで, 赤外領域の分光研究に従 来用いられてきたレーザーのうち，カラーセン ターレーザーは液体窒素温度を必要とする上, 発振波長が1.4 3.6 $\mu \mathrm{m}$ (一部は0.8 $\mu \mathrm{m}$ から)に 限られている。ダイオードレーザー光は3３0 $\mu \mathrm{m}$ 範囲にわたって得られるものの, ひとつ ひとつのダイオードの発振範囲は約 $100 \mathrm{~cm}^{-1} に$ 限られ，広い範囲をカバーするには多数のダイ オードを用意して交換しなければならないし， どのダイオードでもカバーできない「隙間」も 沢山ある。それにここでも液体窒素温度が必要

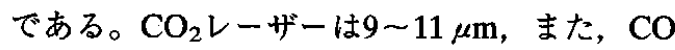
レーザーは5 $6 \mu \mathrm{m}$ と波長領域が限られてお り, かつ, 離散的な発振線しか得られないので, 測定できる对象が限られてしまう。この領域の 広い範囲をカバーする波長可変レーザーは, い ま化学者たちがのどから手が出るほど欲しいも のである。

この領域の波長可变レーザーが最近急速な発 展をみせつつある。筆者は必要があってこの方 面の調查を行い, 1995年9月にはアメリカ,才 レゴン州ポートランドでの米国光学会 (OSA) ミーテイングの光パラメトリック発振 (OPO) のセッションにも出席してその現状をみてき た。この小稿ではそれらを中心に, 筆者の知り えた最近の情報について記し, 読者の参考に供 したいと思う。しかし筆者は化学屋であって レーザーについては一ユーザーにすぎず，誤り や不正確な部分があり得ることをおそれてお ク，それについては御叱正をお願いしたい。ま

*三重大学工学部分子素材工学科レーザー光化学研究グループ (テ514 津市上浜町1515) 分子科学研究所 (T444 岡崎市明大寺町)

* Laser Photochemistry Research Group, Department of Chemistry for Materials, Faculty of Engineering, Mi'e University (1515 Kamihamacho, Tsu 514) and Institute for Molecular Science (Myodaiji, Okazaki 444) 
た,「チャンピオンデータとして発振が達成さ れた」ということょりも,「化学屋として安心 して使えるだろうか」という立場を主にして書 いていることもお断りしておく。

まず, 化学の研究に必要な中赤外レーザーの 性能はどのようなものかについて述べてみる。 化学にも多種多様な実験があるので，この問い にただひと通りの答えを出すことはもちろん不 可能である。しかし大体の見当で例示すれば, 次のようなことにでもなるであろうか。波長領 域はもちろん広いほど良いが, 冒頭にものべた ように5 10 $\mu \mathrm{m}$ は絶対必要である。波長分解 能については, 通常の測定で $1 \sim 0.1 \mathrm{~cm}^{-1}(30$ $3 \mathrm{GHz}$ ), 高分解能測定では気相のDopplerシフ トを考えて $3 \times 10^{-3} \mathrm{~cm}^{-1}(0.1 \mathrm{GHz})$ といったとこ ろであろう。レーザーパワーについては, 定常 状態の線形現象(たとえば吸収スペクトル)の

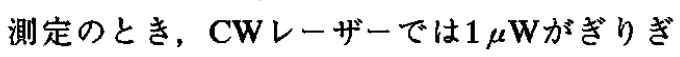
りの線かと思われる。パルスレーザー光では, 時間分解測定ができる。ナノ秒,ピコ秒,フェ ム卜秒領域それぞれで研究できる対象が異な る。必要なパワーは時間領域によって異なるが, ナノ秒領域では $10 \mathrm{~ns}, 10 \mathrm{~Hz}$ として $100 \mu \mathrm{J}$ pulse ${ }^{-1}$ はほい。ピコ秒領域では10ps, 10Hzと

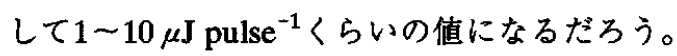
ピコ秒領域の良いところは, キャビテイを組ま なくてすむこと, 分子の通常の吸収スペクトル 測定には分光器なしでもなんとか使えること, 検知法として赤外光を可視光と混合して (upconversionして), 光電子増倍管PCCDカメラを 使用できることである。フェムト秒ではレー ザー光のバンド幅が広くなってしまう(100 $\mathrm{cm}^{-1}$ 以上)ので，これを波長連続光の一部のよ うに考えて, 分光器を使って分散させて吸収ス ペクトル測定を行う必要が生じる。400fs, $1 \mathrm{kHz}, 10 \mathrm{~nJ}$ で吸収スペクトルを測定した例があ るが,もっとパワーがほしいところである。非 線形化学現象の研究では当然もっと大きなレー ザーパワーが必要になる。

\section{2. 光パラメトリック発振 (OPO)}

この領域で波長可変レーザーを発振させるに は, 結局, 光パラメトリック発振 (OPO) ある いは差周波発生 (DFG) によるほかはない。ま ずOPOについて述べる。OPO全般については 本誌 (1993年) に松岡氏と平野氏による紹介論 文1)が載っているので参照されたい。OPOでは， ポンプ光となるパルスレーザー光 (波数 $\left.\nu_{0}\right)$ を 非線形結晶に入射し，その一部を $\nu_{0}=\nu_{\mathrm{s}}+\nu_{\mathrm{i}}$ の関係を満たす二種類の光に変換する。高波数 側の光 $\left(\nu_{\mathrm{s}}\right)$ をシグナル光, 低波数側の光 $\left(\nu_{\mathrm{i}}\right)$ をアイドラー光という。赤外光にはNd:YAG レーザー光などをもとにしたアイドラー光が用 いられる。4.5 $\mu \mathrm{m}$ より短波長の領域のOPOに は応用例もかなりあってコマーシャルな製品も 数社から出ているが, 中赤外領域 $(5 \sim 20 \mu \mathrm{m})$ のものは現在でもまだ開発中というところが塞 情であろう。この領域では, $\mathrm{LiNbO}_{3}, \mathrm{KTP}$, KTA，BBOなどの非線形結晶は吸収があるた め使用できず, $\mathrm{AgGaS}_{2}, \mathrm{AgGaSe}_{2}, \mathrm{ZnGeP}_{2}$ が 用いられる。他に $\mathrm{LiIO}_{3}$ は5.5 $\mu \mathrm{m}$ までの領域な ら使えるが、これらの中で研究報告例があるの はほとんどAgGaS 2 に限られる。レーザー発振 の報告としては，1986年に Eckardt ら ${ }^{2)}$ が Nd:YAG $(1.34 \mu \mathrm{m})$ またはHo:YLF $(2.05 \mu \mathrm{m})$ レーザーをポンプソースとして $\mathrm{AgGaSe}_{2}$ 結晶 を使い, 後者の場合に $10 \sim 30 \mathrm{~ns}, 1 \sim 50 \mathrm{~Hz}$ $2.65 \sim 9.02 \mu \mathrm{m}$ の発振 $(>3 \mathrm{~mJ})$ を得ている。 Lohnerら ${ }^{3)}$ は, モードロックチタンサファイ アレーザーからLBOを用いたOPOで得たシグ ナル光とアイドラー光を $\mathrm{LilO}_{3}$ るいは $\mathrm{AgGaS}_{2}$ 結晶に通して差周波をとり，2.5 5.5 $\mu \mathrm{m}$ 光 $(200 \mathrm{fs}, 82 \mathrm{MHz}$, 平均出力 $500 \mu \mathrm{W})$ を得

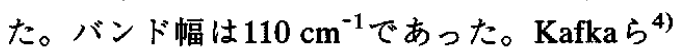
も同様な方法 $(180 \mathrm{fs}, 80 \mathrm{MHz})$ で $\mathrm{AgGaS}_{2}$ 結晶を 使った差周波で2.6 5.3 $\mu \mathrm{m}$ 光 (3.5 $\mu \mathrm{m}$ で平均 $400 \mu \mathrm{W})$ を得た。この場合波長範囲はミラーで 制限されており，12 $\mu \mathrm{m}$ あたりまでのびるはず と報告している。ピコ秒レーザーによる光パラ 
メトリック発生/増幅 (OPG/OPA) を用いた研 究は東工大の広瀬氏と堂免氏 ${ }^{5,6)}$ にっって報告 されている。彼らはピコ秒モードロック Nd:YAGレーザー (35ps) の二倍波を励起源と してBBOによるOPG/OPAによって近赤外光 を出し，これと Nd:YAG レーザーの基本波と の差周波を $\mathrm{AgGaS}_{2}$ でって, $1400 \sim 3000 \mathrm{~cm}^{-1}$ 光を得ている。その赤外光パルスは, 2000

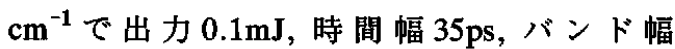
$3.4 \mathrm{~cm}^{-1}$ であるという。OPG/OPAでは光が非 線形結晶を2回通る。まずOPG用の結晶でעs と $\nu_{\mathbf{i}}$ を得たあと, OPA用の結晶に $\nu_{0}$ ととも

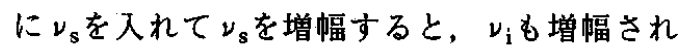
て出力されるのでこれを使用する。彼らはこれ で溶液中のMo $(\mathrm{CO})_{6}$ の振動励起寿命を測定し ている6。

OPOによる中赤外波長可変レーザーのコ マーシャルな製品としては, 現在, 米国の一社 とフランスの一社が名乗りを挙げている。いず れもナノ秒Nd:YAGレーザー $(1.064 \mu \mathrm{m})$ をも とにした初段のOPOでアイドラー光として2.5 的あたりの光を出し，さらにこれをもとにし て、 $\mathrm{AgGaS}_{2}$ まは $\mathrm{ZnGeP}_{2}$ の結晶を用いた二 段目のOPOでアイドラー光として5〜 $10 \mu \mathrm{m}$ (または4 12 $\mu \mathrm{m})$ の中赤外光を出そうとする もののようであるが，いずれもまだ開発中とい うのが実態のようである。

上記ポートランドでの米国光学会 (OSA) ミーテイングでは, Light Solution社のMarshall 氏が “mid-IR” OPOについてレビュー講演を 行った。ただし，この講演での “mid-IR”とは 3〜5 $\mu \mathrm{m}$ のことであった。スラブレーザー技 術の発展によってCWダイオード的起固体レー ザーの大出力のものが得られるようになり，こ れらで pumpして PPLN (periodically poled $\mathrm{LiNbO}_{3}$, 後述), $\mathrm{KTP}$ たはKTAのOPOで得 られる1.4 3.8 $\mu \mathrm{m}$ の波長可変光のうちから $2 \mu \mathrm{m}$ 光を取り出し，さらにKTAまたは $\mathrm{ZnGeP}_{2}$ で二 段目のOPOを行って上記領域の “中赤外”光 (1W以上) が発振できる。3〜 $5 \mu \mathrm{m}$ ののにつ いてはLockheed社のPollok氏らも研究してお
り, $\mathrm{ZnGeP}$ を pumpするにはKTP (KTA)によ るOPOからの $2 \mu \mathrm{m}$ 光が有効であるという。こ のレビュー講演の結論は, 「3〜 $5 \mu \mathrm{m}$ のOPOは すぐにwell-developed になるであろうが，つぎ

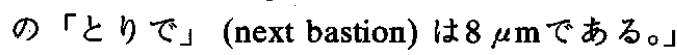
というものであった。

中赤外光を出すためには, Nd:YAGレーザー に基づく二段のOPOよりも，Ho:YLFや Er:YAGレーザーでpumpして一段のOPOにす ればどうかとも考えられる。実際、レーザー発 振という意味では上記Eckardt ら ${ }^{2)} の$ 結果があ る。上記OSAミーテイングでMarshall氏にこ の質問をしてみだ。Ho:YLFレーザー $(2.05 \mu \mathrm{m}$, 6W) をもとにした一段のOPOでこの領域の光 を出す研究は, Lockheed社金下Sanders社の Ian Lee氏らにより進行中であるという。3〜5 $\mu \mathrm{m}$ 光を出すのに二段のOPOと一段のものと どちらが有利であるかを聞いたところ,まず“It is a good question.”といわれた。現状では Ho:YLFレーザーの高繰り返しを得るのに冷却 $(200 \mathrm{~K})$ を要するなどの問題点がある。したがっ て，一段のOPOが二段のものより原理的に効 率が良いはずとはいっても，現時点では $2 \mu \mathrm{m}$ 光を仲介とする二段のOPOの方が現実的であ ろうというのが氏の見解であった。しかし上記 Sanders社のIan Lee 氏ら は, 常温で働く Ho:YLF レーザーを開発中であるという。 Ho:YLFのかわりにEr:YAGを用いることも考 えられるが, Er:YAGには複屈折性, 効率の悪 さの様な問題点が多いとのことであり，これは もうひとつ先の課題になるようである。しかし アメリカではこの方面の需要が多く(軍事用な どか?), 開発の進み方が速いので, 一年さきに はかなり情勢が変わるかもしれない。

\section{3. 差周波発生 (DFG)}

つぎに周波発生 (DFG)法について述べる。 この方法では二種類の光 $\nu_{1}$ と $\nu_{2}$ を非線形結晶 に入射して, 差周波光 $\left(\nu_{1}-\nu_{2}\right)$ を出力させる。 レーザー発振そのものについては，OPOにも とづく上記LohlerらやKafkaらの報告のほか, 
CWモードロックNd:YAGレーザーと白色光連 続帯 (WLC) に $\mathrm{LiIO}_{3}$ 結晶を用いるJedjuと Rothbergの例 $(2.3 \sim 5.5 \mu \mathrm{m})^{8)}$, 一台のチタン サファイアレーザーからの 2 波長の光を利用し たBarrosとBeckerの報告9)などがある。

差周波法ではこれを使った分光研究例もいく つかある。まずフェムト秒の例としては，米国 のHammら ${ }^{10,11)}$ が, フェムト秒のチタンサファ イアレーザー+再生増幅器 (Regen) からの $815 \mathrm{~nm}$ 光 (120fs) と進行波色素レーザー $(\mathrm{TWDL})^{12,13)}$ の光について $\mathrm{AgGaS}_{2}$ 結晶の中で 差周波をとり, 5〜 11 $\mu \mathrm{m}, 300 \sim 400 \mathrm{fs}, 10 \mathrm{~nJ} の$ 中赤外光を得て, 試料の吸収スペクトルの測定 に使っている。この場合, 中赤外光のバンド幅

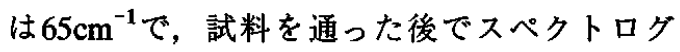
ラフで分光し, スペクトル分解能 $3 \sim 10 \mathrm{~cm}^{-1}$, 吸光度 (OD) の確度は $0.1 \mathrm{~m}$ ODであるという。 最近彼らは，この方法を紫色細菌Rhodobacter sphaeroides (R26) の反応中心の時間分解赤外 スペクトル $\left(1000 \sim 1800 \mathrm{~cm}^{-1}\right)$ 測定に適用して いる ${ }^{14)}$ 。上記OPAミーテイングでの発表によ ると, Hachee氏 (トロント大) ${ }^{14 a)}$ はチタンサファ イアレーザー (80 fs) から KTP のsynchronously pumped (SP) OSOで得た $1550 \mathrm{~nm} と 1650 \mathrm{~mm}$ 光 とから $\mathrm{AgGaSe}_{2}$ 結晶の中で差周波をとり，8～ $18 \mu \mathrm{m},<20 \mu \mathrm{W}$ の光を得た。 $16 \mu \mathrm{m}$ でのバンド 幅は $\Delta \lambda=2.0 \mu \mathrm{m}$, 時間幅600fsであった。この 方法の限界はシグナル光, アイドラー光と差周 波光の三種の光のwalk-offおよび, 差周波のパ ルスの時間幅の広がりにあるという。

つぎにサブピコ秒の例として, $\mathrm{LiIO}_{3}$ 結晶を 差周波法発生に用いているので1800～4000 $\mathrm{cm}^{-1}$ に限られるが, DoughertyとHeilweil ${ }^{15)}$ は サブピコ秒Nd:YAGレーザー (acousto-opticに モードロックしたCWレーザー) からの光を KTPで2倍波にした $532 \mathrm{~nm}$ 光 $(5 \mathrm{ps}, 82 \mathrm{MHz})$ で2 台の色素レーザー (DCM, 658nmとローダミン $6 \mathrm{G}, 578 \mathrm{~nm})$ を発振させ, 始めのサブピコ秒 Nd:YAGレーザー光をフラッシュランプ $(20 \mathrm{~Hz})$ 励起のNd:YAG再生増幅器 (Regen) 2 段で增幅した後にKD*Pで二倍波にした532nm
光 $(25 \mathrm{~mJ})$ で2個の三段色素アンプをpumpし, 上記のDCMとローダミン $6 \mathrm{G} の$ 色素レーザー光 をそれぞれこの三段色素アンプで増幅した後に $\mathrm{LiIO}_{3}$ で差周波をとり, バンド幅 $100 \mathrm{~cm}^{-1}$ の赤 外光を得ている。吸収測定には試料透過後の赤 外光パルスをDCM光の残りとともに $\mathrm{LiIO}_{3}$ 結 晶中で和周波をとってup-conversionし, 可視 光にしてダブルモノクロメーターで分光し, 分 解能 $4 \mathrm{~cm}^{-1}$ としてCCD検知器で検出している。 彼らはこの装置を用いて $\mathrm{Cr}(\mathrm{CO})_{6}$ のピコ秒過 渡吸収スペクトルを得ている ${ }^{15)}$ 。また $\mathrm{Cp}{ }^{*} \mathrm{Ir}$ $(\mathrm{CO})_{2}\left(\mathrm{Cp}{ }^{*}=\eta^{5}\right.$-ペンタメチルシクロペンタ ジエニル)のモード固有赤外励起によるピコ秒 過渡吸収スペクトルを得ている ${ }^{16)}$ 。中赤外 OPO/DFGのコマーシャルな製品としては, 最 近,ピコ秒Nd:YAGレーザーをもとにした Eksma社のものが出ている。

CW光による研究として, 米国Rice大のTittel, Curl ${ }^{17,18)}$ は, アルゴンイオンレーザー (20W) でポンプした2台の安定化単一周波数 CW色素/チンサファイア・リング色素レー ザー (DCM とローダミン 6G)を発振させ, $\mathrm{AgGaS}_{2}$ 結晶で差周波をとり, 7〜9 $\mu \mathrm{m}$ でバン ド幅の狭い (0.5MHz以下) $1 \mu \mathrm{W}$ 出力を得て, アンモニアなどの気体分子の精密分光を行って いる。検出にはHgCdTe検知器を使用している。 $\mathrm{AgGaSe}_{2}$ 結晶を用いると, 4 18 $\mu \mathrm{m}$ の赤外光 を発生させることができる ${ }^{19)}$ 。最近，野外で も使用できる小型の差周波スペクトロメーター の必要性から，2台のダイオードレーザーを用 いる差周波赤外レーザーも開発されてきた。 Simon $\check{5}^{20)}$ は, 東芝TOLD 9140 (s) ダイオード レーザー (690nm, $10.1 \mathrm{~mW})$ とシャープLT010 MD ダイオードレーザー $(808 \mathrm{~nm}, 1.93 \mathrm{~mW})$ を 使って, $2115 \mathrm{~cm}^{-1}$ で3.3nWの赤外光を得ること に成功している。Petrovら ${ }^{21)}$ は, 800nmのダイ オードレーザーと, ダイオードでポンプした Nd:YAG レーザー $(1064 \mathrm{~nm})$ の差周波を $\mathrm{AgGaSe}_{2}$ 結晶を用いてとり, $3.2 \mu \mathrm{m}$ 付近の波 長可変赤外光を出して, 空気中のメタンの検出 に用いている。 
ここで中赤外には使えないけれども, periodically poled $\mathrm{LiNbO}_{3}$ (PPLN) についてふ れておく。始めにしるした9月のOSAミーテイ

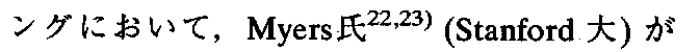
これについて講演した。一方向に分極して生成 された単結晶の表面にマイクロリソグラフィー の方法で電極をつけてこれに高電圧 (例として $21 \mathrm{kV} / \mathrm{mm})$ をかけ，数十 $\mu \mathrm{m} こ ゙ と に$ 交互に逆向 きに分極した結晶をつくる。これの利点は，非 線形係数が大きくなる，位相整合の条件がcriticalでなくなる，許容角が大きくなる，Walkoff がないことである。分極が交替する周期を 変えた結晶を何枚も重ねて $(26 〜 32 \mu \mathrm{m}, 0.5 \mu \mathrm{m}$ ごと)多重格子をつくりだし，これを光路に垂 直な方向にマイクロメーターで押して平行移動 させ, 光が通る部分の結晶の分極の周期を次々 と変えていくことによって出てくるOPO光を tune することができる $(1 \mathrm{~cm}$ の移動で1.36〜 $4.84 \mu \mathrm{m}$ の範囲)。なお，この種の結晶は共同研 究者の Bosenberg 氏 (Lightwave Electronics Co.) から購入できるという。上記 Rice大の Curl氏 ${ }^{24)}$ は，1995年8月にカナダのヴィクトリ アで開かれ筆者も出席した遊離基国際シンポ ジウムにおいて，この種のPPLN結晶を用いた
気相化学反応研究の結果を報告していた。

\section{4. まとめ}

中赤外領域波長可変レーザーの現状を Table Iにまとめておいたが, 化学屋としてみた場合, 中赤外領域のOPOにはまだ未解決の問題が多 く，現状ではDFGの方が使いやすいようであ る。しかし中赤外DFGの使用例は，いまのと ころ吸収スペクトル (時間分解を含む) の測定 に限られている。ダイナミックな現象の研究に 使うにはDFGではレーザー光のパワーが不足 かもしれない。OPOの光にはパワーの点など から大きな魅力がある。波長分解能の点からは ナノ秒が良いのだが, Eckardtらの1986年の仕 事 ${ }^{2)}$ があるのにナノ秒領域の研究が進んでいな いのは, $\mathrm{AgGaS}_{2}$ の damage threshold が低いせ いだろうか。中赤外のOPOは今のところまだ 使いにくいけれども，世界的，とくにアメリカ での進歩はたいへん速いので，つねに注目し ていなければならない。OPOも数年の内に はかなり使いやすくなる可能性もある。それ にしても最大のbottleneckは，やはり damage thresholdの高い非線形結晶の開発にあるとい う感じを禁じ得ない。

Table I Typical performance of OPO and OPO/DFG devices

\begin{tabular}{|c|c|c|c|c|c|c|}
\hline Method & Pulse width/rep-rate & Crystal & $\begin{array}{l}\text { Wavelength } \\
\text { range }\end{array}$ & $\begin{array}{l}\text { Band } \\
\text { width }\end{array}$ & Power & Lit. \\
\hline OPO & $10-30 \mathrm{~ns} / 1-50 \mathrm{~Hz}$ & $\mathrm{AgGaSe}_{2}$ & $2.65-9.02 \mu \mathrm{m}$ & & $>3 \mathrm{~mJ}$ & 2) \\
\hline OPO/DFG & $200 \mathrm{fs} / 82 \mathrm{MHz}$ & $\begin{array}{l}\mathrm{LBO} / \mathrm{LiIO}_{3} \\
\mathrm{AgGaS}_{2}\end{array}$ & $2.5-5.5 \mu \mathrm{m}$ & $110 \mathrm{~cm}^{-1}$ & $500 \mu \mathrm{W}$ & 3) \\
\hline OPO/DFG & $180 \mathrm{fs} / 80 \mathrm{MHz}$ & LBO/AgGaS 2 & $2.6-5.3 \mu \mathrm{m}$ & & $400 \mu \mathrm{W}$ & 4) \\
\hline OPG/OPA/DFG & $35 \mathrm{ps} / 10 \mathrm{~Hz}$ & $\mathrm{BBO} / \mathrm{AgGaS}_{2}$ & $3.3-7.1 \mu \mathrm{m}$ & $3.4 \mathrm{~cm}^{-1}$ & $0.1 \mathrm{~mJ}$ & $5,6)$ \\
\hline DFG & $350 \mathrm{fs} / 10 \mathrm{~Hz}$ & $\mathrm{LiIO}_{3}$ & $2.3-5.5 \mu \mathrm{m}$ & $500 \mathrm{~cm}^{-1}$ & & 8) \\
\hline DFG & $50-70 \mathrm{fs} / 85 \mathrm{MHz}$ & $\mathrm{AgGaS}_{2}$ & $9 \mu \mathrm{m}$ & $14-15 \mathrm{~nm}$ & $0.03 \mathrm{pJ}$ & 9) \\
\hline DFG & $400 \mathrm{fs} / 1 \mathrm{kHz}$ & $\mathrm{AgGaS}_{2}$ & $\begin{array}{l}4.5-11.5 \mu \mathrm{m} \\
5-11 \mu \mathrm{m}\end{array}$ & $\begin{array}{l}60 \mathrm{~cm}^{-1} \\
65 \mathrm{~cm}^{-1}\end{array}$ & $\begin{array}{l}>10 \mathrm{~nJ} \\
10 \mathrm{~nJ}\end{array}$ & 10) \\
\hline DFG & $<600 \mathrm{fs} / 85 \mathrm{MHz}$ & $\mathrm{AgGaS}_{2}$ & $8-18 \mu \mathrm{m}$ & & $<20 \mu \mathrm{W}$ & 14a) \\
\hline DFG & $1.5 \mathrm{ps} / 20 \mathrm{~Hz}$ & $\mathrm{LiIO}_{3}$ & $\sim 4.8 \mu \mathrm{m}$ & $100 \mathrm{~cm}^{-1}$ & $5 \mu \mathrm{J}$ & $15,16)$ \\
\hline DFG & $\mathrm{CW}$ & $\mathrm{AgGaS}_{2}$ & $7-9 \mu \mathrm{m}$ & $\begin{array}{l}<0.5 \mathrm{MHz} \\
\left(1.5 \times 10^{-5} \mathrm{~cm}^{-1}\right)\end{array}$ & $1 \mu \mathrm{W}$ & $17,18)$ \\
\hline
\end{tabular}




\section{参考文 献}

1) 松岡正浩, 平野㻟也：レーザー研究 21 (1993) 76 .

2) R. C. Eckardt, Y. X. Fan, R. L. Byer, C. L. Marquardt, M. E. Storm and L. Esterowitz: Appl. Phys. Lett. 49 (1986) 608.

3) A. Lohner, P. Kruck and W.W.Ruhle: Appl. Phys. B59 (1994) 211.

4) J. D. Kafka, M. L. Watts, J. W. Pieterse and R. L. Herbst: Appl. Phys. B60 (1995) 449.

5) C. Hirose: in Advances in Multi-Photon Processes and Spectroscopy, eds. S. H. Lin and Y. Fujimura (Vol.9, World Scientific, 1995) pp.143-197.

6) 和田昭英, 横田敏也, A. Bandara, 柳沼道雄, 久保田純, 野村淳子, 狩野覚, 堂免一成, 広 瀬千秋：分子構造総合討論会, 1995年9月, 仙 台.

7) Ian Lee: private communication.

8) T. M. Jedju and L. Rothberg: Appl. Opt. 27 (1988) 615 .

9) M. R. X. de Barros and P. C. Becker: Opt. Lett. 18 (1993) 631.

10) P. Hamm. C. Lauterwasser and W. Zinth: Opt. Lett. 18 (1993) 1943.

11) P. Hamm, S. Wiemann, M. Zurek and W. Zinth: Opt. Lett. 19 (1994) 1642.

12) T. Elsaesser and M. C. Nuss: Opt. Lett. 16 (1991) 411.
13) J. Hebling and J. Kuhl: Opt. Lett. 14 (1989) 278.

14) P. Hamm, M. Zurek, W. Mantele, M. Meyer, H. Scheer and W. Zinth: Proc. Natl. Acad. Sci. 92 (1995) 1826.

14a) A. Hachee, private communication.

15) T. P. Dougherty and E. J. Heilweil: Opt. Lett. 19 (1994) 129.

16) W. T.Grubbs, T. P. Dougherty and E. J. Heilweil: Chem. Phys. Lett. 227 (1994) 480.

17) P. Canarelli, Z. Benko, R. Curl and F. K. Tittel: J. Opt. Soc. Am. B9 (1992) 197.

18) A. H. Hielscher, C. E. Miller, D. C. Bayard, U. Simon, K. P. Smolka, R. F. Curl and F. K. Tittel: J. Opt. Soc. Am. B9 (1992) 1962.

19) U. Simon, Z. Benko, M. W. Sigrist, R. F. Curl and F. K. Tittel: Appl. Opt. 32 (1993) 6650.

20) U. Simon, C. E. Miller, C. C. Bradley, R. G. Hulet, R. F.Curl and F.K. Tittel: Opt. Lett. 18 (1993) 1062.

21) K. P. Petrov, S. Waltman, U. Simon, R. F. Curl, F. K. Tittel, E. J. Dlugokencky and L. Hollberg: Appl. Phys. B61 (1995) in press.

22) L. E. Myers, R. C. Eckardt, M. M. Fajer, R. L. Byer, W. R. Bosenberg and J. W. Pierce: J. Opt. Soc. Am., Feature Issue on Optical Parametric Devices (1995) submitted.

23) L. E. Myers: private communication.

24) R. F. Curl: private communication. 